\title{
PRODUKSI PROTEASE ALKALI DAN KERATINASE DARI Brevibacillus agri A-03 TERMOFILIK
}

\author{
Anthoni Agustien ${ }^{1}$, Jetty Nurhajati ${ }^{2}$, Linar Z. Udin ${ }^{3}$, Pingkan Aditiawati ${ }^{4}$ \\ ${ }^{1}$ Universitas Andalas Padang \\ ${ }^{2}$ Universitas Padjadjaran Bandung, \\ ${ }^{3}$ Lembaga Ilmu Pengentahuan Indonesia (LIPI) Bandung \\ ${ }^{4}$ Institut Teknologi Bandung \\ email : aagustien@gmail.com
}

\begin{abstract}
ABSTRAK
Protease alkaline and keratinase are a group of protease enzym which have important value in detergen industry and skin tannery. Brevibacillus agri A-03 is thermophilic bacteria isolate that comes from Ambayan Sumatera Barat hot spring and has the ability to produce protease and keratinase. The purpose of this research is to get protease alkaline and thermostable keratinase from Brevibacilus agri-A03. thermostable enzym is produced from enzym production enzym that contains kasein and keratin at various medium $\mathrm{pH}$, inoculum incubation temperature and medium type. Enzym activity is measured by modified Walker methode, protein content is measured by Lowry methode. Protease alkaline is produced at exponential phase, maximum at $18^{\text {th }}$ hours of incubation and keratinase is produced at stationer phase, maximum at $22^{\text {nd }}$ hours. Both enzym is produced optimically at medium $\mathrm{pH}$ condition 9.0 ; incubation temperature $55^{\circ} \mathrm{C}$, inoculum $5 \%$ by using modified Johnvesly and Naik medium with each protease and keratinase specific activity 1.927 and $1.047 \mathrm{U} / \mathrm{mg}$
\end{abstract}

Keywords: Protease alkaline, Keratinase, Thermofilic, Brevibacillus agri A-03

\section{PENDAHULUAN}

Penelitian yang intensif dilakukan untuk mengisolasi bakteri termofilik dari beberapa habitat dengan tujuan penggunaan mikroba dan enzim yang dihasilkannya untuk diterapkan dalam bidang bioteknologi ${ }^{[1]}$. Penggunaan bakteri termofilik dalam bidang industri cenderung meningkat, disebabkan aplikasi enzim dalam bioteknologi memerlukan enzim yang tahan panas ${ }^{[2]}$. Salah satu sumber penghasil enzim termostabil adalah bakteri termofilik, kebanyakan dari bakteri termofilik yang diteliti adalah dari genus Bacillus yang diisolasi dari lingkungan termal ${ }^{[3]}$.

Menurut Johnvesly dan Naik, Bacillus menjadi perhatian utama dalam bioteknologi sebab mikroba ini relatif mudah untuk isolasi dari berbagai macam lingkungan dan mampu untuk tumbuh dalam media sintetik ${ }^{[4]}$. Kemampuan berbagai jenis Bacillus yang berbeda dalam kemampuannya untuk melakukan proses fementasi pada kondisi $\mathrm{pH}$ asam, netral, alkali serta kombinasi dengan adanya yang bersifat termofilik, berindikasi untuk dikembangkan dalam menghasilkan enzim yang stabil terhadap suhu tinggi ${ }^{[3]}$.

Bacillus dapat menghasilkan protease termostabil yang digunakan dalam berbagai bidang, terutama untuk industri deterjen dan penyamakan kulit. Protease merupakan enzim yang paling penting, karena $60 \%$ hasil produksi industri enzim di seluruh dunia adalah protease dan $25 \%$ diantaranya bersifat termostabil. Bacillus spp. dapat menghasilkan protease alkali yang banyak digunakan sebagai bahan aditif deterjen yang bernilai ekonomis ${ }^{[5]}$ dan keratinase yang sering digunakan dalam penyamakan kulit ${ }^{[6]}$.

Jenis Bacillus yang menghasilkan protease dan keratinase secara bersamaan, dengan menggunakan satu jenis medium produksi 
enzim adalah Bacillus pumilus FH9 bersifat mesofilik yang diisolasi dari tanah ${ }^{[6]}$.

Brevibacillus agri A- 03 termofilik berasal dari sumber air panas Ambayan Sumatera Barat yang memiliki aktivitas enzim protease alkali dan keratinase termostabil yang paling tinggi ${ }^{[7]}$. Untuk memproduksi enzim yang mempunyai aktivitas yang tinggi sehingga dapat digunakan dalam aplikasinya, maka haruslah dilakukan optimalisasi terhadap mikroorganisme.

Bertitik tolak dari uraian di atas maka perlu dilakukan penelitian produksi protease alkali dan keratinase termostabil dari Brevibacillus agri A-03 dengan tujuan untuk mengetahui kemampuan Brevibacillus agri A-03 termofilik menghasilkan protease alkali dan keratinase serta mengetahui kondisi lingkungan ekstrinsik yang menyebabkan Bacillus sp. termofilik dapat memproduksi protease alkali termostabil dan keratinase yang optimal.

\section{METODOLOGI}

Mikroorganisme yang digunakan sebagai sumber protease alkali dan keratinase adalah Brevibacillus agri A-03 termofilik. Medium "Thermophilic Bacillus" digunakan sebagai media pemeliharaan isolat. Medium El-Refai yang telah dimodifikasi digunakan sebagai medium produksi enzim.

Pengukuran aktivitas protease dan keratinase ditentukan dengan metode Walker yang dimodifikasi. Kadar protein ditentukan dengan metode Lowry. Penentuan profil kurva pertumbuhan dan aktivitas enzim. Optimisasi ekstrinsik parsial yang dilakukan mencakup waktu produksi enzim, induser yang digunakan, pH medium, suhu inkubasi produksi enzim, jumlah inokulum dan jenis medium.

\section{HASIL DAN DISKUSI}

\section{Profil Kurva Pertumbuhan Bakteri dan Aktivitas Enzim}

Profil pertumbuhan bakteri dan aktivitas spesifik enzim yang dihasilkan seperti disajikan pada Gambar 1.

Gambar 1 menunjukkan hubungan pertumbuhan bakteri dengan produksi protease dan keratinase. Pertumbuhan bakteri yang sangat cepat dimulai pada 2 jam inkubasi sampai pada 18 jam inkubasi (fase eksponensial), selanjutnya pertumbuhan bakteri mengalami statis sampai pada 22 jam (fase stasioner), kemudian populasi bakteri mengalami peningkatan pada jam ke 32 inkubasi dan pertumbuhan bakteri statis sampai jam ke 36, akhirnya populasi bakteri menurun mulai 38 jam inkubasi.

Protease dari sel bakteri disekresikan pada medium, dimulai pada jam ke 2 inkubasi dan dihasilkan maksimum pada 18 jam inkubasi. Keratinase ekstraseluler dihasilkan sel bakteri dimulai pada 20 jam inkubasi dan dihasilkan secara maksimum pada 32 jam inkubasi. Protease dihasilkan selama fase eksponensial dan maksimum pada fase eksponensial yang diperlambat dan diawal fase stationer. Hal ini menunjukkan bahwa protease dari Brevibacillus agri A-03 termasuk metabolit primer. Keratinase dihasilkan pada saat fase stationer, sehingga keratinase dari Brevibacillus agri A-03 dikategorikan termasuk kepada metabolit sekunder.

Menurut Crueger dan Crueger, metabolit primer dihasilkan mikroorganisme pada saat pertumbuhan eksponensial dan metabolit sekunder dihasilkan pada fase stationer ${ }^{[8]}$. Protease biasanya dihasilkan maksimum pada antara akhir fase eksponensial dan awal fase stasioner $^{[9]}$. 


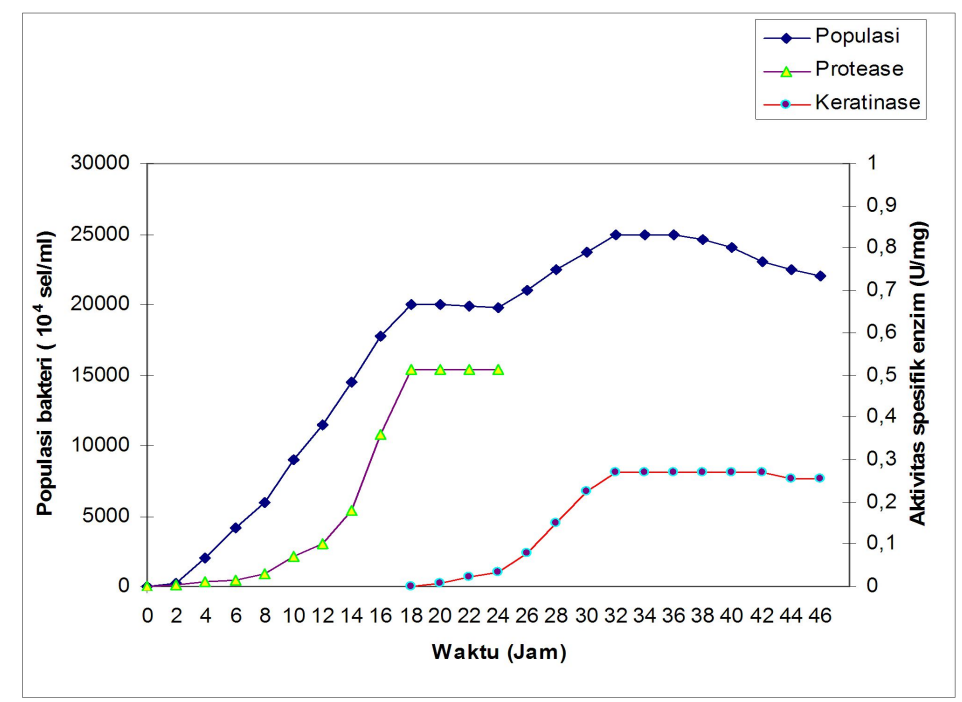

Gambar 1. Profil pertumbuhan Brevibacillus agri A-03 dan aktivitas protease dan keratinase.

Menurut Kumar dan Takagi, penghasilan protease dari mikroorganisme dapat berlangsung pada (1) selama selama fase eksponensial, (2) dimulai pertengahan fase eksponensial dan (3) fase stasioner. Protease dan keratinase dari Brevibacillus agri A-03 dihasilkan pada waktu yang berbeda ${ }^{[10]}$. Hal yang berbeda dilaporkan bahwa Bacillus licheniformis PWD-1 menghasilkan protease dan keratinase secara bersamaan pada fase stasioner $^{[1]}$.

Gambar 1 juga menunjukkan pada sel bakteri terjadi regulasi biosintesis enzim, dimana protease terlebih dahulu dihasilkan dan setelah terjadi kecendrungan penurunan populasi bakteri yang diikuti dengan aktivitas spesifik protease yang cenderung menurun, serta dengan adanya keratin pada medium menyebabkan sel bakteri terinduksi untuk biosintesis keratinase yang kemudian mensekresikannya pada medium. Keratinase ekstraseluler yang dihasilkan, menghidrolisis keratin yang ada pada medium dengan produk berupa oligopeptida dan asam amino yang merupakan sumber nutrisi bagi bakteri sehingga populasi bakteri mengalami peningkatan kembali. Menurut Onifade, keratinase yang disekresikan ke medium akan mendegradasi substrat keratin yang menghasilkan asam amino dan sulfur yang berguna untuk sel mikroorganisme.

\section{Efek Induser Terhadap Aktivitas Enzim}

Medium produksi enzim yang mengandung masing-masing induser kasein, pepton dan ekstrak khamir, memiliki aktivitas protease namun tidak memiliki aktivitas keratinase. Medium produksi enzim yang mengandung induser keratin, memiliki aktivitas keratinase namun tidak memiliki aktivitas protease. Sedangkan jika pada medium produksi enzim mengandung kedua induser kasein dan keratin, memiliki aktivitas protease dan keratinase. Hal ini menunjukkan bahwa pada sel Brevibacillus agri A-03, kasein hanya menginduksi biosintesis protease dan keratin menginduksi biosintesis keratinase (Gambar 2).

Suhartono, melaporkan bahwa kasein, pepton dan ekstrak khamir merupakan induser yang menginduksi biosintesis protease pada kelompok bakteri Bacillus ${ }^{[2]}$. Menurut Cai, kasein, susu bubuk dan pepton tidak dapat menginduksi produksi keratinase dari mikroorganisme, hanya substrat keratin yang dapat menginduksi biosintesis keratinase ${ }^{[12]}$. Hal yang berbeda dilaporkan Sivasubramanian, bahwa Bacillus subtilis MTCC 6537 yang ditumbuhkan di medium yang mengandung kasein dan ampas kacang kedele, menghasilkan protease yang mempunyai aktivitas enzim penghilang bulu ${ }^{[13]}$.

Gambar 2 juga menunjukkan bahwa medium yang mengandung induser keratin, menginduksi biosintesis keratinase pada sel 
isolat A-03 tetapi tidak dapat menginduksi biosintesis protease. Menurut Son, enzim keratinolitik sebagian besar induktif yang memerlukan keratin sebagai induser, Bacillus megaterium F7-1 meng-hasilkan keratinase dengan menggunakan bulu ayam sebagai induser ${ }^{[14]}$. Menurut Todar, umumnya bakteri tidak mensintesis enzim yang bersifat degradasi jika substrat dari enzim tersebut tidak ada pada lingkungannya ${ }^{[15]}$. Mikroorganisme pen-degradasi makromolekul keratin, umumnya memproduksi keratinase jika diinduksi oleh adanya substrat keratin ${ }^{[16]}$. Fenomena yang berbeda dari $B$. licheniformis PWD-1, B. cereus B5esz dan Bacillus sp. 45, yang memiliki kemampuan mensintesis protease dan keratinase dari medium yang mengandung bulu ayam ${ }^{[11,17-18]}$.

\section{Efek Suhu Inkubasi dan pH Medium Terhadap Aktivitas Enzim}

Efek suhu terhadap aktivitas protease dan keratinase pada $\mathrm{pH}$ medium 9, lebih jelasnya dapat dilihat pada Gambar 3.

Gambar 3 menunjukkan suhu optimum untuk memproduksi protease dan keratinase dengan aktivitas enzim yang maksimum adalah pada suhu $55^{\circ} \mathrm{C}$. Brevibacillus agri A-03 tumbuh dan menghasilkan protease dan keratinase pada rentang suhu yang luas antara $45-60^{\circ} \mathrm{C}$, dengan kondisi seperti ini Brevibacillus agri A-
03 sangat berpotensi menghasilkan enzim termostabil. Johnvesly dan Naik, melaporkan bahwa Bacillus sp. JB99 dapat tumbuh dan menghasilkan protease alkali pada rentang suhu yang luas antara $30-60^{\circ} \mathrm{C}$ dengan protease maksimum dihasilkan pada suhu $55^{\circ} \mathrm{C}$, namun enzim tidak dihasilkan pada suhu di bawah $30^{\circ} \mathrm{C}$ dan di atas $60^{\circ} \mathrm{C}^{[4]}$. Bacillus licheniformis merupakan mikroorganisme yang sangat potensial digunakan sebagai sumber enzim untuk degradasi bulu, karena bersifat termofilik yang dapat hidup pada suhu tinggi $50-65^{\circ} \mathrm{C}$.

Gambar 4 menunjukkan bakteri yang ditumbuhkan pada rentang $\mathrm{pH}$ medium produksi enzim mulai dari $\mathrm{pH} 7$ sampai $\mathrm{pH} 10$, dapat menghasilkan protease dan keratinase dengan aktivitas spesifik enzim yang berbeda. $\mathrm{pH}$ medium yang optimum untuk memproduksi protease dan keratinase adalah medium dengan $\mathrm{pH}$ 9. Kondisi fermentasi merupakan faktor penting untuk penghasilan enzim. Bacillus sp. yang ditumbuhkan pada lingkungan alkali menghasilkan enzim proteolitik lebih tinggi dibandingkan bila bakteri tersebut ditumbuhkan pada lingkungan netral ${ }^{[19]}$. $\mathrm{pH}$ optimum untuk memproduksi enzim dari Bacillus firmus 7728 yang digunakan sebagai bahan penyamak kulit adalah pada $\mathrm{pH} 9,0^{[20]}$.

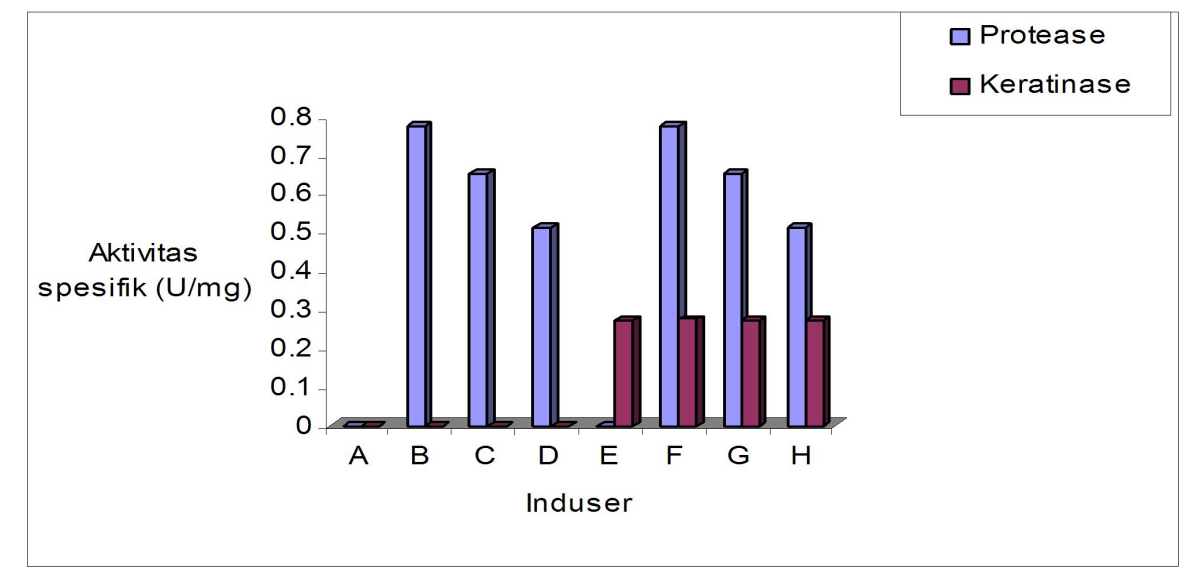

Gambar 2. Histogram pengaruh induser terhadap produksi protease dan keratinase.

Keterangan : $\mathrm{A}=$ Kontrol $/$ tanpa induser, $\mathrm{B}=$ Kasein $1 \%, \mathrm{C}=$ Pepton $0,1 \%, \mathrm{D}=$ Ekstrak khamir $0,5 \%, \mathrm{E}=$ Keratin $1 \%, \mathrm{~F}=$ Kasein $1 \%$ + Keratin $1 \%, \mathrm{G}=$ Ekstrak khamir $0,1 \%+$ Keratin $1 \% \mathrm{H}=$ Pepton $0,5 \%+$ Keratin $1 \%$ 


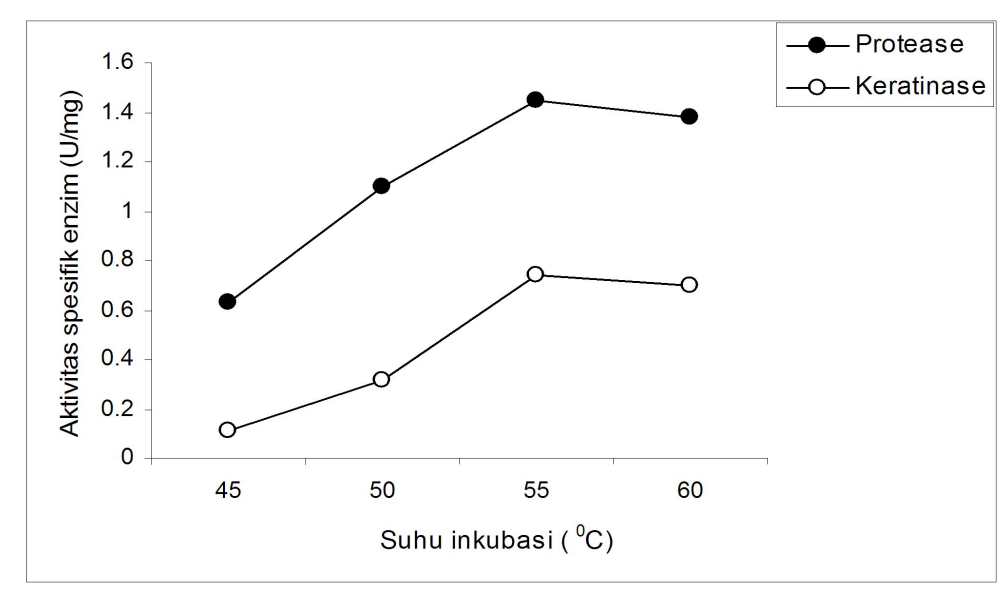

Gambar 3. Profil suhu inkubasi terhadap aktivitas spesifik enzim pada $\mathrm{pH}$ medium 9.

\section{Efek Inokulum dan Jenis Medium Terhadap Aktivitas Enzim}

Efek konsentrasi inokulum pada medium Johnvesly dan Naik yang telah dimodifikasi disajikan pada Gambar 5.

Gambar 5 menunjukkan konsentrasi inokulum yang digunakan pada kultur bakteri memberikan pengaruh terhadap produksi enzim. Konsentrasi inokulum 5\%, merupakan konsentrasi inokulum yang optimum untuk menghasilkan protease dan keratinase yang paling tinggi. Pada konsentrasi inokulum 5\%, aktivitas spesifik protease dan keratinase, masing-masing sebesar $1,927 \mathrm{U} / \mathrm{mg}$ dan 1,047 $\mathrm{U} / \mathrm{mg}$.

Menurut Shafee, peningkatan produksi protease dengan menggunakan konsentrasi yang sesuai diperkirakan disebabkan rasio antara permukaan area yang besar dengan volume, menyebabkan produksi protease menjadi meningkat ${ }^{[21]}$. Konsentrasi inokulum $5 \%$ digunakan untuk produksi enzim protease dari Bacillus $^{[22]}$. Konsentrasi inokulum 5\% dari Bacillus licheniformis FK 46 termotoleran merupakan konsentrasi yang terbaik dalam menghasilkan keratinase ${ }^{[23]}$. Penggunaan konsentrasi inokulum yang lebih kecil $(2,5 \%)$ menyebabkan produksi enzim menurun yang dapat dilihat dari aktivitas spesifik protease dan keratinase masing-masing $0,420 \mathrm{U} / \mathrm{mg}$ dan $0,090 \mathrm{U} / \mathrm{mg}$. Menurut Shafee, jika digunakan konsentrasi inokulum yang lebih kecil, menyebabkan ketidakcukupan bagi bakteri untuk menghasilkan protease sehingga mengurangi jumlah enzim yang disekresikan [21].

Menurut Stanbury dan Whitaker, konsentrasi inokulum memberi pengaruh terhadap lamanya fase lag, dimana waktu yang panjang pada fase lag tidak menguntungkan, tidak hanya pemborosan waktu, tetapi juga nutrisi dikonsumsi untuk pemeliharaan sel sebelum tumbuh $^{[22]}$. Konsentrasi inokulum yang lebih besar $(7,5 \%)$, juga menunjukkan produksi enzim menurun, yang terlihat dari aktivitas spesifik protease dan keratinase masingmasing $0,880 \mathrm{U} / \mathrm{mg}$ dan $0,333 \mathrm{U} / \mathrm{mg}$.

Konsentrasi inokulum yang lebih besar dapat mengakibatkan oksigen terlarut menjadi berkurang dan terjadinya peningkatan kompetisi akan nutrisi ${ }^{[21]}$. Produksi keratinase menurun dengan peningkatan konsentrasi inokulum di atas konsentrasi inokulum dengan aktivitas enzim yang maksimum ${ }^{[12]}$.

Gambar 6 menunjukkan semua jenis medium dapat menghasilkan protease dan keratinase, dimana bakteri yang ditumbuhkan pada medium Johnvesly dan Naik ( $\mathrm{J}$ dan $\mathrm{N}$ ) yang telah dimodifikasi menunjukkan produksi enzim yang paling tinggi dengan aktivitas spesifik protease dan keratinase sebesar 1,927 $\mathrm{U} / \mathrm{mg}$ dan 1,047. Kemudian medium Casein Broth (CB) dengan aktivitas spesifik protease dan keratinase sebesar $1,462 \mathrm{U} / \mathrm{mg}$ dan 0,751 $\mathrm{U} / \mathrm{mg}$.

Medium El-Refai yang telah dimodifikasi (kontrol) dengan produksi protease dan 
keratinase sebesar $1,45 \mathrm{U} / \mathrm{mg}$ dan $0,742 \mathrm{U} / \mathrm{mg}$. Medium Gelatin Broth (GB) menghasilkan aktivitas spesifik protease $1,277 \mathrm{U} / \mathrm{mg}$ dan keratinase 0,650 U/mg. Medium Mecedo menghasilkan aktivitas spesifik protease 0,942 $\mathrm{U} / \mathrm{mg}$ dan keratinase $0,437 \mathrm{U} / \mathrm{mg}$. Aktivitas spesifik protease dan keratinase berbeda pada jenis medium produksi enzim yang berbeda, hal ini disebabkan komposisi masing-masing medium produksi enzim yang digunakan berbeda. Komposisi medium Johnvesly dan Naik mengandung kalsium dan $\mathrm{NaCl}$ yang tidak terdapat pada medium produksi lainnya. Formulasi medium yang baik sangat penting untuk mendapatkan perolehan hasil yang maksimum $^{[22]}$. Penggunaan medium Macedo ternyata menghasilkan protease dan keratinase yang paling rendah, hal ini disebabkan pada medium Macedo, terdapat "whey milk" dengan kadar laktosa yang tinggi dan kaya akan asam amino. "Whey milk" mengandung 94\% air, 5\% laktosa; $0,9 \%$ protein dan $0,1 \%$ lemak. Jadi kemungkinan terjadi represi dari laktosa dan asam amino yang terdapat pada medium produksi enzim terhadap biosintesis sel bakteri dalam menghasilkan protease dan keratinase. Komposisi medium adalah sangat penting untuk menghasilkan enzim ${ }^{[19]}$. Sumber karbon dengan konsentrasi yang tinggi pada medium, dapat berperan sebagai represor katabolit sehingga terjadi penurunan produksi enzim ${ }^{[24]}$. Asam amino yang terdapat pada medium produksi enzim akan menyebabkan terjadinya represi terhadap biosintesis enzim proteolitik ${ }^{[2]}$. Medium Macedo selain mengandung "whey milk", juga mengandung bulu sapi dengan konsentrasi 4\%. Tingginya konsentrasi bulu sapi pada medium dapat menekan produksi keratinase. Keratin dengan konsentrasi yang tinggi antara $3-5 \%$ yang terdapat medium produksi enzim, akan menyebabkan penekanan produksi keratinase dari Bacillus sp. FK 46 ${ }^{[24]}$.

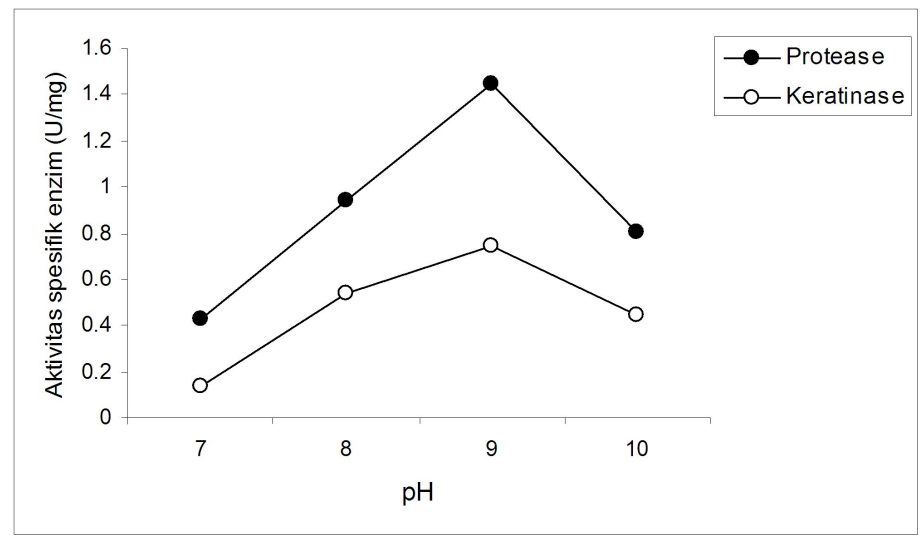

Gambar 4. Profil $\mathrm{pH}$ medium terhadap aktivitas spesifik enzim pada suhu $55^{\circ} \mathrm{C}$.

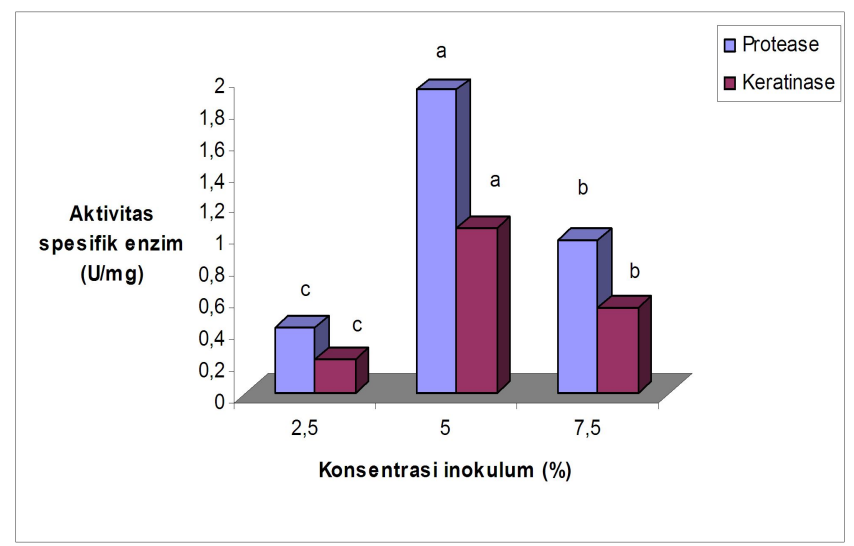

Gambar 5. Histogram pengaruh konsentrasi inokulum terhadap aktivitas enzim pada medium Johnvesly dan Naik. 


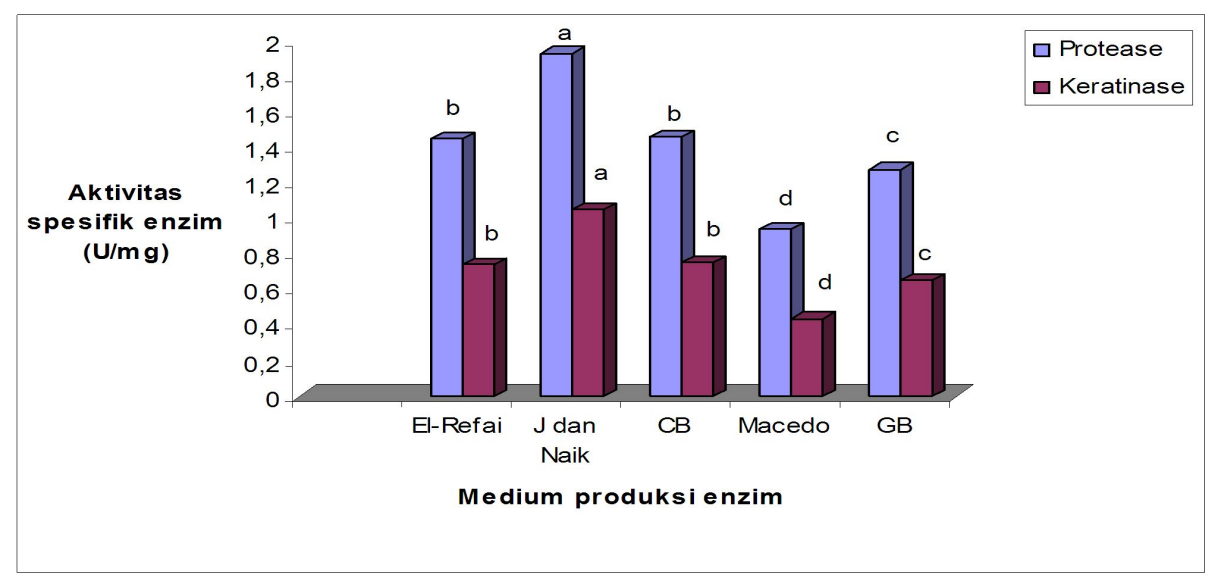

Gambar 6. Histogram efek jenis medium produksi terhadap aktivitas enzim pada konsentrasi inokulum 5\%.

\section{KESIMPULAN}

Dari penelitian yang telah dilakukan dapat disimpulkan bahwa produksi protease alkali pada 18 jam inkubasi sedangkan keratinase pada 22 jam. Suhu inkubasi dan $\mathrm{pH}$ medium untuk produksi enzim adalah suhu $55^{\circ} \mathrm{C}$ dan $\mathrm{pH}$ 9. Produksi enzim menggunakan inokulum 5\% dengan medium Johnvesly dan Naik yang telah dimodifikasi.

\section{DAFTAR PUSTAKA}

1. A. N. Souza, and M.L.L. Martins, Isolation, properties and kinetics of growth of a thermophilic Bacillus, Brazillian J. Microbiology, 32(4), (2001).

2. M. T. Suhartono, Protease, PAU Bioteknologi IPB, Bogor, 1991.

3. M. Schallmey, A. Singh and O. P. Ward, Developments in the use of Bacillus species for industrial production, Canadian J. Microbiology, 50: 1-17, (2003).

4. B. Johnvesly, and G. R. Naik, Study on production of thermostable alkaline protease from thermophilic and alkaliphilic Bacillus sp. JB99 in a chemically defined medium, J. Process Biochem., 37: 139-144, (2001).

5. M. B. Rao, A. M. Tanksale, M. S. Gahtge and V. V. Deshpande, Moleculer and biotechnological aspects of microbial proteases, Microbiology Biology Review, 62: 597-635, (1998).
6. H.A. El-Refai, M.A. Abdelnaby, A. Gabala, M. H. El-Araby and A.F.A. Fattah, Improvement of the newly isolated Bacillus pumilus FH9 keratinolyti activity, Process Biochem., 40: 2325 2332, (2005).

7. A. Agustien, Isolasi dan Identifikasi Bacillus spp. Proteolitik dan Keratinolitik dari Sumber Air Panas Sumatera Barat, $J$. Biospectrum, 6(1): 26-33, (2010).

8. W. Crueger, and A. Crueger, A Text Book of Industrial Microbiology, Ed. T.D. Brock, Sinauer Associates Inc, New York, 1984.

9. Y. Y. Feng, W.B. Yang S. L. Ong and J.Y. $\mathrm{Hu}$, Fermentation of starch for alkaline protease production by constructing an alkalophilic Bacillus pumilus strains, Appl. Microbiology Biotech., 57: 153 - 160, (2001).

10. C. G. Kumar, and H. Takagi, Microbial alkaline proteases from a bioindustrial viewpoint, Biotechn. Advance, 17, 561594, (1999).

11. S.W. Cheng, H.M. Wu, S.W. Shen, H. Takagi, M. Asano and Y.C. Tsai, Production and characterization of keratinase of a feather degrading $B$. licheniformis PWD-1, Biosience, Biotech. and Biochem., 59: 2239 - 2243, (1995).

12. C. Cai, , B. Lou and X. Zheng, Keratinase production and keratin degradation by mutant strains of Bacillus subtilis, $J$. of Zhejiang University Sci. B., 9: $60-67$, (2008).

13. S. Sivasubramanian, B.M. Manohar, A. Rajaram and R. Puvanakrishnan, Eco- 
friendly lime and sulfide free enzymatic dehairing of skins and hides using a bacterial alkaline protease, Chemosphere, 70: 1015-1024, (2008).

14. H. J. Son, G. T. Park and Y. G. Kim, Production of a keratinolytic protease by a feather-degrading bacterium, Bacillus megaterium F7-1, Korea J. Microbiology, 40: 43-48, (2004).

15. K. Todar, The Genus Bacillus, Todar's online textbook of bacteriology, University of Wisconsin-Madison, Madison, 2009.

16. R. Gupta, and P. Ramnani, Microbial keratinase and their prospective application: an overview, Applied Microbiology Biotech., 70(1): 21-33 (2006).

17. Rodziewicz and W. Laba, Biodegradation of feather keratin by Bacillus cereus in pure culture and compost, Electronic $J$. Agricultural Universities, 11(2), (2008).

18. D.J. Daroit. A.P.F. Correa and A. Brandelli, Keratinolytic potential of a novel Bacillus sp. P45 isolated from the Amazon basin fish Piaractus mesopotamicus, International Biodeteriration \& Biodegradation, (in press), $1-6$, (2009).
19. A. N. Glazer, and H. Nikaido, Microbial enzyme in: Microbial Technology, Fundamentals of Applied Microbiology, W.H. Freeman and Company, New York, 1995.

20. K. Rao, and M. L. Narasu, Alkaline protease from Bacillus firmus 7728 , African J. of Biotechn., 6(21): 2493-2496, (2007).

21. N. Shafee, S. N. Aris, R.N.Z.A. Rahman, M. Basri and A.B. Saleh., Optimization of environmental and nutritional conditions for the production of al- kaline protease by a newly isolated bacterium Bacillus cereus strains 146, J. Applied Sci. Research, 1(1): 1-8, (2005).

22. P.F. Stanbury, and A. Whitaker, Principles of Fermentation Technology, Pergamon Press, Oxford, 1984.

23. W. Suntornsuk, and Suntornsuk, L, Feather degradation by Bacillus sp. FK 46 in submerged cultivation, Bioresource Techn., 86(3): 239-243, (2003).

24. N. A. Klimov, V. T. Batarin, O. V. Rybalchenko and O. A. Andreev, Formation of extracellular protease by cells of thermophilic bacteria, Microbiology, 57: 579-585, (1988). 